\title{
One Nation, Three Faiths: World War I and the Shaping of "Protestant-Catholic-Jewish" America
}

\author{
DAVID MisLIN
}

\begin{abstract}
During World War I, American political, military, and religious leaders sought to foster the view that protestants, Catholics, and Jews were equal stakeholders in society. Crucial in shaping the embrace of this "tri-faith" ideal were leading members of all three traditions, who used their connections to the federal government to ensure that many facets of national life reflected this new conception of the nation's religious character. The military chaplaincy put these ideals into practice, and interfaith activity became commonplace in the army. Protestant, Catholic, and Jewish chaplains worked closely together, and provided pastoral care or offered religious rites to wounded and dying soldiers from different faith traditions. This article examines how the wartime break from political and social normality, the desire to project a particular image of the nation abroad, and Americans' firsthand encounter with religion in Europe all contributed to idealizations of the inclusive nature of American civil religion during World War I. Yet, as this essay demonstrates, the transitional nature of wartime culture and the strong role of the federal government in fostering these values prevented this outlook from firmly taking root. The experience did, however, provide a critical precedent for subsequent idealizations of a protestant-Catholic-Jewish nation.
\end{abstract}

$\mathrm{T}$ wo defining features marked the American rabbi Lee J. Levinger's service as an army chaplain in World War I. The first was the inescapable reality of death during the conflict and even after it had ended. Just days before his departure for home in the spring of 1919, an accident at sea near Brest harbor claimed the lives of four American sailors. Their deaths provided Levinger with one final encounter with the second defining characteristic of his time in Europe: the need to provide religious services to people of different faith traditions. Levinger, it turned out, was

The author is grateful to Jon Roberts, Brooke Blower, Matthew Hedstrom, Gene Zubovich, Andrew Ballou, Sara Georgini, Kevin Schultz, Healan Gaston, Mark Silk, and Chris Beneke for their comments on this essay at various stages of its development.

David Mislin is Assistant Professor in the Intellectual Heritage Program at Temple University. 
the only clergyman of any religious affiliation at Brest. The task of "burying four Christian boys" thus became a Jewish rabbi's final act of wartime service. ${ }^{1}$

During his eight months in France, which had included a tour of duty at the front, Levinger often found himself ministering to non-Jews. It was "almost matters of everyday," he recounted, that soldiers from other traditions came to him in moments of profound need. "I . . have read psalms at the bedside of dying Protestant soldiers. I have held the cross before a dying Catholic," Levinger wrote, affirming his belief that during the war "we were all one in a very real sense." Other chaplains recounted nearly identical experiences. Charles H. Brent, an Episcopalian who served as chief of the army chaplaincy corps, described the image of "the Jew carrying the crucifix to a dying Catholic" as one of his most indelible memories of the conflict. Another protestant chaplain reported providing "religious ministrations to every man" in his unit, "Catholic, Protestant, and Jewish" alike. ${ }^{2}$

Moreover, interreligious encounters occurred not just in situations where clergy from one tradition provided such "religious ministrations" to soldiers of another. During the months in which Levinger remained in France after the armistice (like many other American military personnel, he had to wait for transport to become available), he was assigned to burial duty. He passed the time while performing that somber work by "discussing the fundamental principles of Judaism and Christianity" with a group that consisted of "Catholic, Baptist, Christian, Christian Scientist and Jew." Throughout the war, the rabbi had observed similar occurrences among ordinary soldiers, which had prompted many of them to set aside longstanding assumptions and prejudices in favor of new feelings of sympathy and appreciation. Levinger noted that the war brought together the "Jew from the East Side of New York, who had never known any Christian except the corner policeman" with the "Kentucky mountaineer, who had been reared with the idea that Jews have horns," and both "were bound to be broadened" by the experience. ${ }^{3}$

Lee Levinger was correct, and not merely about his two anecdotal soldiers; World War I marked a broadening experience for much of American society. Personal interaction and close cooperation among protestants, Catholics, and Jews were frequent occurrences, especially for those Americans connected to the military and the federal government. More importantly, such instances were celebrated both as they happened and in subsequent recollections of

\footnotetext{
${ }^{1}$ Lee J. Levinger, A Jewish Chaplain in France (New York: Macmillan, 1921), 79.

${ }^{2}$ Ibid., 137; Charles H. Brent, "Unity," 1919 Sermon Notebook, box 27, Charles Henry Brent Papers, Manuscript Division, Library of Congress, Washington D.C.; "Press Release of the National Catholic War Council," enclosed with John J. Burke to Robert E. Speer, December 17, 1918, folder 14, box 5, National Catholic War Council Records, Catholic University of America Archives, Washington, D.C..

${ }^{3}$ Levinger, A Jewish Chaplain in France, 51, 133.
} 
wartime experience. Ultimately, the war inspired many Americans to reconsider how they described the nation's religious identity. For reasons ranging from the practical to the idealistic, the conflict prompted them to embrace the characterization of the United States as a place where Catholics and Jews were full political, cultural, and religious equals to protestants. In this idealized vision, Judaism and Catholicism no longer seemed decidedly inferior to or different from the protestant Christianity long viewed by its adherents as the nation's normative faith. Prominent leaders emphasized that members of all three traditions believed in the same God and shared the same patriotic commitment to the nation. On the basis of these similarities, it was possible, they argued, to set aside all other matters of faith in order to form "an invincible army" for "the common good." In the view of these leaders, issues that for centuries had proved divisive within Christianity and between Christians and Jews - things like the divinity of Jesus, the identity of the Messiah, the nature of authority and the structure of Christian churches, and countless other major issues of doctrine-constituted little more than minor theological differences. ${ }^{4}$

To be sure, the first stirrings of what recent historians have labeled the "trifaith" ideal began long before the United States entered Europe's Great War. Indeed, World War I was not even the first military conflict to bring protestants, Catholics, and Jews into closer contact. During the Revolutionary War, one Catholic served as a military chaplain, and sporadic efforts to foster inclusiveness had existed in the early republic. A few dozen Catholic priests became chaplains during the Civil War, although they typically served only for a short duration and found their efforts hampered by the anti-Catholic sentiments of protestant military leaders. Nevertheless, they helped to orchestrate instances of shared worship and prayer between Catholic and protestant soldiers. Jews, too, served as chaplains during the Civil War, though not without considerable effort. The legislation authorizing a chaplaincy corps initially stipulated that only ordained ministers of a "Christian denomination" could serve, and it required a concerted lobbying campaign to have the language amended to "religious denomination." Nor did World War I bring a complete shift in cultural values. While Catholics and Jews no longer had to negotiate for a place at the table as they had in previous years (in part because of their newfound numerical strength as a result of decades of immigration), there were many aspects of the wartime experience that belied the inclusive rhetoric that many leaders espoused. It would take several decades more - and the nation's

${ }^{4}$ Roy B. Guild, "The Church, the Community, and the Present Crisis" (1918), folder 10, box 75, Federal Council of the Churches of Christ in America Records, Presbyterian Historical Society, Philadelphia, Pa. 
participation in an even bloodier conflict—-before the ideals expressed during the Great War took root in society at large. ${ }^{5}$

Nevertheless, the First World War did mark a critical moment for interfaith relations, as major political, military, and religious leaders enthusiastically embraced the vision of a protestant-Catholic-Jewish United States. These prominent figures sought to make government policy reflective of this ideal and to foster such sentiments at the grassroots level. In other words, leading Americans were committed to the full inclusion of Catholics and Jews in national life at the war's outset, and for the first time in the country's history, a large effort went into ensuring that reality matched this ideal. This project was far from universally successful. Protestant-Catholic hostility lingered throughout the war, and anti-Semitism remained entrenched in much of military life, as Jewish soldiers faced impediments to advancement and outright discrimination and hostility. Nevertheless, the very existence of such an effort signaled a major departure from how members of America's three major religious traditions had historically interacted with one another in the public sphere. $^{6}$

This essay chronicles the history of this important moment in the development of the idealization of a tri-faith United States. It first emphasizes a central ingredient in the enactment of this new outlook: the

\footnotetext{
${ }^{5}$ On the broader trajectory toward the acceptance of religious diversity in the decades before World War I, see William R. Hutchison, Religious Pluralism in America: The Contentious History of a Founding Ideal (New Haven, Conn.: Yale University, 2003), 111-128; on Catholic chaplains during the Revolutionary war, and the broader tendency toward ecumenism in the early republic, see Charles H. Metzger, "Chaplains in the American Revolution," Catholic Historical Review 31, no. 1 (April 1945): 279; Chris Beneke, "The "Catholic Spirit Prevailing in Our Country': America's Moderate Religious Revolution," in The First Prejudice: Religious Tolerance and Intolerance in Early America, ed. Chris Beneke and Christopher S. Grenda (Philadelphia: University of Pennsylvania, 2011), 279-280; Chris Beneke, Beyond Toleration: The Religious Origins of American Pluralism (New York: Oxford University, 2006); on the inclusion of Catholics and Jews during the Civil War, see Randall M. Miller, "Catholic Religion, Irish Ethnicity, and the Civil War," in Religion and the American Civil War, ed. Randall M. Miller, Harry S. Stout, and Charles Reagan Wilson (New York: Oxford University, 1998), 263268; on the campaign to allow Jewish chaplains, see Albert Isaac Slomovitz, The Fighting Rabbis: Jewish Military Chaplains and American History (New York: New York University, 1999), 10-20. On the widespread emergence of the "tri-faith" ideal during and after World War II, see Kevin M. Schultz, Tri-Faith America: How Catholics and Jews Held America to its Postwar Protestant Promise (New York: Oxford University, 2011); Mark Silk, Spiritual Politics: Religion and America Since World War II (New York: Simon and Schuster, 1988), 40-53; Wendy L. Wall, Inventing the "American Way": The Politics of Consensus from the New Deal to the Civil Rights Movement (New York: Oxford University, 2008), 143-148; Deborah Dash Moore, G.I. Jews: How World War II Changed a Generation (Cambridge, Mass.: Belknap University, 2004), 10-11. For an exploration of how the experience of World War I contributed to subsequent idealizations, see Thomas A. Bruscino, A Nation Forged in War: How World War II Taught Americans To Get Along (Knoxville: University of Tennessee, 2010), ch. 1.

${ }^{6}$ For representative instances of anti-Semitism during World War I, see Leonard Dinnerstein, Antisemitism in America (New York: Oxford University, 1994), 75-77.
} 
Committee of Six. After the United States entered the war, protestant, Catholic, and Jewish leaders all developed grave concerns about the moral state of the war-zone. They perceived the importance of exerting pressure on the War Department to provide a strong religious influence on the troops, preferably one provided by military chaplains. As members of all three traditions realized their common concern, they grew to appreciate the value of combined action. The Committee of Six-made up of four protestants, one Catholic, and one Jew-embodied this new conception of the nation's spiritual landscape. By serving as the principal conduit between America's religious institutions and government officials who saw the benefit of such an interfaith group, the committee ensured that policymakers would view all three traditions as crucial stakeholders in national life. Despite the relative obscurity of the group, the mere fact that national leaders perceived its necessity was enormously significant. Its very existence would prove to be a lasting legacy of the war.

The Committee of Six was also instrumental in negotiating the difficulties that resulted from this new effort to advance interfaith cooperation. Its members worked to solve profound problems of religious identity that arose during World War I, such as whether Catholicism and Judaism should be treated as "faiths" that were analogous to protestantism as a whole or as "denominations" that were equivalent to specific branches of protestantism (such as Methodism or Presbyterianism). The answer to this question had profound ramifications for the representation of various religious groups in the military, and more broadly, in the nation at large. In urging consensus in favor of the view that they were, in fact, fully-fledged faiths, the Committee of Six helped grant the Catholic and Jewish traditions the stature they needed for the ideal of a protestant-Catholic-Jewish nation to take root.

While the Committee of Six embodied this new tri-faith ideal and expressed it in the policy sphere, its message was echoed by participants in similar endeavors throughout the nation. Within the military, the interfaith chaplaincy corps helped to ensure that the religious life of the armed forces reflected the nation's diversity. The chaplaincy emerged as an essential vehicle for advancing interfaith encounter, shared ministry, and common worship on the battlefields of Europe. These experiences abroad, as recounted by men like Lee Levinger, helped to advance a spirit of inclusiveness among soldiers, which in turn further strengthened the widespread image of American society as encompassing Jews and Catholics as well as protestants. ${ }^{7}$

\footnotetext{
${ }^{7}$ For a useful history of the independent activities of American religious institutions during the war, see John F. Piper, Jr., The American Churches in World War I (Athens: Ohio University, 1985); for perspective on religion in wartime from the perspective of soldiers, see Jonathan $\mathrm{H}$.
} 
There were two important factors that limited this popular image, both of which seem worth acknowledging at the outset. First, this conception of America's religious landscape resulted nearly as much from practical concerns - the belief that inclusion of Catholics and Jews in wartime fundraising efforts would lead to greater financial returns, for example - as it did from lofty ideals. Second, the military and federal government served as crucial venues for modeling and encouraging inclusive religious values. The expanded authority granted to these institutions proved essential for accomplishing this goal. Yet, its dependence on the military and government, combined with its roots in meeting the exigencies of war, explains the fleeting nature of this wartime idealization of a tri-faith society. The end of the conflict left proponents without institutional homes from which to continue to advance their agenda. Nevertheless, the experience of World War I inspired an ongoing commitment to these ideals among many participants who helped lay the foundation for the wider popularization of such sentiments in the mid-twentieth century. ${ }^{8}$

Ultimately, this is a history of America's civil religion, and specifically how it became redefined and reimagined during World War I. Scholars of religion in the United States have long noted the way in which military conflicts have served to reinforce what Robert Bellah identified as the central tenet of American civil religion: that the United States is a chosen nation, set apart by God to be a beacon for the world. Though Bellah and others have noted that civil religion was not identical with Christianity, both belief systems shared many assumptions, including an emphasis on sacrifice, as well as the common imagery of death and rebirth. Many scholars, including Jonathan $\mathrm{H}$. Ebel, have also suggested that the shared sense of national purpose that frequently occurs during wartime provides a particularly strong inspiration for unifying ideologies. Moreover, the nature of the military-with its emphasis on uniformity, common action, and solidarity of purpose - is the ideal venue to put such ideals into practice. The Civil War has long been viewed as the prime example of a historical moment in which widespread unanimity existed about the nature of America's Civil Religion. While both

\footnotetext{
Ebel, Faith in the Fight: Religion and the American Soldier in the Great War (Princeton, N.J.: Princeton University, 2010).

${ }^{8}$ For other scholarship that identifies World War I as a transformative moment in American culture, see Christopher Capozzola, Uncle Sam Want You: World War I and the Making of the Modern American Citizen (New York: Oxford University, 2008); Nancy Gentile Ford, Americans All!: Foreign-Born Soldiers in World War I (College Station: Texas A\&M University, 2001); Jennifer D. Keene, Doughboys, the Great War, and the Remaking of America (Baltimore, Md.: Johns Hopkins University, 2001); David M. Kennedy, Over Here: The First World War and American Society, 25th Anniversary Edition (New York: Oxford University, 2004).
} 
sides emphasized elements of this ideology, the victorious North was especially adept at viewing the war through the lens of a Christ-like blood sacrifice and rebirth. ${ }^{9}$

But if the bloody conflict of the early 1860 s was crucial in defining the core tenets of civil religion, the Great War a half-century later proved equally pivotal in inspiring a broadening of the groups encompassed in this civic creed. That World War I would do so is unsurprising. As a conflict couched in moral terms and undergirded by rhetoric promising that the conflict would help bring God's kingdom to earth, and with America's enemies portrayed as irreligious and its allies depicted as spiritually sapped, the war offered a prime opportunity for the United States to declare itself once again to be a godly, chosen nation. But for the first time - at least in the view of religious leaders, military officials, and political elites-Catholics and Jews were equal partners with protestants in carrying out America's moral mission in the world.

\section{The Committee of Six and the Federal Government's INTERFAITH EFFORTS}

The official entry of the United States into World War I in 1917 all but guaranteed that American soldiers would be dispatched to Europe, which prompted fears within religious communities that these young men would come under the sway of influences deleterious to their moral health. Protestant, Catholic, and Jewish leaders all concluded that the spiritual and moral well-being of soldiers could not be left to the military, and within each tradition an effort emerged to ensure a religious influence throughout the armed forces. Though international protestant groups like the Young Men's Christian Association (YMCA) had been active in Europe since the outbreak of hostilities in 1914, American protestants sought to employ their own institutions. The war afforded an ideal occasion to test the strength of the nine-year-old Federal Council of the Churches of Christ in America, which had been established to ensure the efficient coordination of the efforts of various protestant denominations in the interest of social reform. World War I presented an opportunity to attempt interdenominational cooperation on a larger scale, and Federal Council leaders maneuvered to ensure that they would assume primary responsibility for the religious and moral health of

\footnotetext{
${ }^{9}$ Robert N. Bellah, "Civil Religion in America," Daedalus 96, no. 1 (Winter 1967): 1-21; Jonathan H. Ebel, "Of the Lost and the Fallen: Ritual and the Religious Power of the American Soldier," The Journal of Religion 92, no. 2 (April 2012): 227-229. On civil religion in the Civil War, see George C. Rable, God's Almost Chosen People: A Religious History of the American Civil War (Chapel Hill: University of North Carolina, 2010), 3-5.
} 
America's soldiers. Less than a week after Congress voted to declare war on Germany, the organization's leaders established the Committee for the Moral and Religious Welfare of the Army and Navy, which would work to develop a corps of chaplains to "uplift the personnel" of the military. ${ }^{10}$

American Catholic leaders were equally convinced of the "staggering" problem of immoral behavior among troops in war zones. Noting that during the previous year's failed attempt to capture Pancho Villa, moral conditions among American soldiers along the Mexican border had been "horrible to the last degree," one cleric asserted that ignoring such problems "would have been treason to our priesthood." Other prominent Catholics concurred, observing that "the souls, as well as the bodies, of our sons and brothers in the camps and in the field are imperiled." But while Catholics shared protestants' sense of urgency, they lacked the centralized structure for decision-making that the Federal Council provided. "A vast amount of confusion became evident," as Catholic bishops disagreed with one another about the appropriate strategy for coordinating wartime activities. The Knights of Columbus, a nationwide fraternal organization, proclaimed its commitment to providing enough chaplains to meet the needs of Catholic troops. But it soon became apparent that the laity-led organization could not undertake such an effort without the involvement of the hierarchy of priests and bishops. The task of securing military chaplains, Catholic leaders agreed, required "the hearty co-operation" of the "authorized and qualified leaders" of the American church. ${ }^{11}$

In the early months of the war, American protestant and Catholic leaders followed parallel paths. In May of 1917, the Federal Council established the General War-Time Commission of the Churches (GWCC), which brought together over one hundred protestants under the leadership of Robert E. Speer, a Presbyterian layman who had spent much of his career overseeing the foreign mission projects of both his own denomination and the Federal Council. Concerns about morality were central to this new interdenominational group, as Speer explained that its major focus was addressing "the moral and religious problem on the other side of the sea."12

\footnotetext{
10، Extracts from the Minutes of the Administrative Committee of the Federal Council of the Churches of Christ in America," April 12, 1917, folder 8, box 70, Federal Council of the Churches of Christ in America Records; for a useful history of the founding of the Federal Council, see Samuel M. Cavert, The American Churches in the Ecumenical Movement, 1900 1968 (New York: Association Press, 1968); on broader anxieties about morality in World War I, see Capozzola, Uncle Sam Wants You, 117-143.

${ }^{11}$ William Kerby to J.T. O'Connell, August 17, 1917, folder 1, box 1, National Catholic War Council Records; M.J. Lavelle to the Bishops of the United States, October 9, 1917, ibid.; Piper, The American Churches in World War I, 23-24.

${ }^{12}$ Robert E. Speer, "Opening Address of the General War-Time Commission of the Churches," February 22, 1918, folder 10, box 70, Federal Council of the Churches of Christ in America Records.
} 
Three months later, the National Catholic War Council (NCWC) was established with the sanction of the church hierarchy, and it assumed many of the functions previously conducted by the Knights of Columbus. The priest John J. Burke, editor of the widely read periodical Catholic World, served as the council's president. It was reflective of the gulf that separated Catholics and protestants in early twentieth-century America that members of each tradition favored having their own organization, despite the shared belief that a chaplaincy corps represented the ideal vehicle for ensuring the moral and religious health of soldiers. ${ }^{13}$

Jews, too, initially worked independently to support the war effort. In part, this reflected the need to respond to unique elements of the Jewish experience, including widely held pacifist commitments and the antipathy of many recent immigrants toward historically unsympathetic European governments. Leaders of the Jewish Welfare Board had the same goals as their Catholic and protestant counterparts, however. They lobbied for a military chaplaincy to which rabbis received appointments and sought to guarantee that Jewish soldiers could engage freely in their religious practices while in the military. ${ }^{14}$

The maintenance of separate institutions did not preclude close cooperation among Catholic, protestant, and Jewish leaders. Soon after the NCWC's establishment, John Burke expressed his group's desire to work with the GWCC to achieve their common goals. The protestant organization quickly appointed a committee to meet with Catholic representatives "and to cooperate in whatever way may be possible." The GWCC designated one of its members, the Presbyterian minister and Union Seminary professor William Adams Brown, "to confer with Father Burke . . . in reference to moral conditions in Europe." Such interactions bore immediate fruit. Within a week, leaders of the major constituent denominations of the Federal Council submitted a petition in support of a chaplaincy corps to President Woodrow Wilson, Secretary of War Newton D. Baker, and members of Congress. The document's protestant signers noted that their petition was "fully approved" by "official representatives of the Catholic Church," including two cardinals: James Gibbons of Baltimore (the elder statesman of the American church) and New York's John Farley. Soon, cooperation expanded to include Jews as well. A request from the GWCC to Woodrow Wilson for a national "day of penitence and prayer" noted that although "the Roman Catholics and the Hebrews" were not official members of the group,

\footnotetext{
${ }^{13}$ Piper, American Churches in World War I, 69-85.

${ }^{14}$ On the formation of the Jewish Welfare Board and Jewish reaction to entry to the war, see Christopher M. Sterba, Good Americans: Italian and Jewish Immigrants During the First World War (New York: Oxford University, 2003), 77-78, 153-155.
} 
there was "hearty cooperation" among representatives of all three traditions "in matters relating to the war."15

This perception that America's religious communities would achieve greater success if they banded together underlay the most significant institutional manifestation of interfaith cooperation during World War I: the Committee of Six. The committee originated in an informal group of prominent protestant, Catholic, and Jewish leaders that John Burke assembled to discuss shared concerns about "the moral and physical welfare of our troops overseas." In October of 1917, Burke arranged a meeting in Washington with Raymond Fosdick, the chairman of the National Commission on Training Camp Activities, to discuss policies favored by the group, including "the suppression of disorderly houses" in areas where American troops were to be stationed. Burke encouraged his protestant and Jewish associates to attend the meeting with him. "I organized the strongest committee that I could," he explained, "in order to show the government how strongly American religious opinion demanded an improvement in both France and Great Britain." The priest traveled to Washington with four leaders of influential religious groups: Williams Adams Brown of the Federal Council of Churches; John R. Mott, the general secretary of the YMCA; Harry Cutler of the Jewish Welfare Board; and James DeWolf Perry, Jr., representing the Episcopal Church (although Episcopalians cooperated with the Federal Council, they did not officially join the ecumenical group until 1940, and thus sought to have their own representation in interfaith efforts). ${ }^{16}$

The group that Burke brought to Washington exemplified the change since the Civil War, during which protestant churches enjoyed a near monopoly on officially sanctioned religious work. Fifty years later, it was possible for a Catholic clergyman to assemble a committee of protestants and Jews, all of whom shared a commitment to interfaith action. Government officials proclaimed the same commitment. "The small committee . . consisting of representatives of the Protestant, Catholic, and Jewish faiths," Raymond Fosdick observed, "seems to me to be a very useful piece of machinery." He suggested that the group stay together "as a sort of informal advisory committee, so that we might be free to call upon you for information and assistance in connection with our perplexing problems." Nor was he the only

\footnotetext{
15“Minutes of the Meeting of the General War Commission of the Churches," September 20, 1917, folder 9, box 70, Federal Council of the Churches of Christ in America Records; "Minutes of the Meeting of the Executive Committee of the General War-Time Commission of the Churches," September 20, 1917, ibid.; "Petition from the Federal Council of Churches to the President, Secretary of War, Congress," September 27, 1917, ibid.; Members of the General War-Time Commission of the Churches to Woodrow Wilson, October 20, 1917, ibid.

${ }^{16}$ John J. Burke to Raymond B. Fosdick, October 11, 1917, folder 9, box 70, Federal Council of the Churches of Christ in America Records; John J. Burke to Edmond F. Prendergast, November 10, 1917, folder 5, box 5, National Catholic War Council Records.
} 
federal official who saw the benefit of such a group. Less than a week after their initial consultation with Fosdick, the group was summoned back to Washington to meet with Secretary of War Baker. ${ }^{17}$

The membership of the Committee of Six was completed with the addition of Robert E. Speer, the head of the GWCC, and the group played an active role in shaping government and military policy during World War I. After persuading Congress to authorize a chaplaincy corps, the committee continued to lobby for a reduction in the ratio of chaplains to soldiers. Committee members also pressured Congress to extend the draft exemption to students at theological seminaries, noting, in typical fashion, that they were speaking for "all the Protestant, Catholic, and Jewish churches" and representing members of all three faiths. ${ }^{18}$

The Committee of Six also worked to foster interfaith understanding in the military. Its members inspected the War Department's training school for military chaplains at Camp Zachary Taylor, where they examined the curriculum. Their report on it urged that chaplains needed to possess greater knowledge about how different religious groups-including the YMCA, the Knights of Columbus, and the Jewish Welfare Board-were supporting the war effort. Committee members were also adamant that individual chaplains understand the key beliefs and practices of traditions besides their own. Speaking for the committee, Burke requested that the War Department produce a handbook describing "the principal, fundamental tenets of the various denominations," so that each chaplain might have "an intelligent understanding of the men whom he must serve of denominations other than his own." Such information would allow military clergy to "extend real help in the hour of great suffering and of death." Henry Pinckney McCain, who as Adjutant General oversaw the army's administrative operations, expressed his full support for the committee's "important" suggestion and promised the immediate production of such handbooks. ${ }^{19}$

As the Committee of Six sought to foster feelings of commonality among protestants, Catholics, and Jews, the group itself experienced considerable

\footnotetext{
${ }^{17}$ Raymond B. Fosdick to John J. Burke, November 3, 1917, folder 5, box 5, National Catholic War Council Records; Burke to Prendergast, November 10, 1917, ibid.; on the protestant-led relief agencies in the Civil War, see Drew Gilpin Faust, This Republic of Suffering: Death and the American Civil War (New York: Knopf, 2008), 107-117; Anne C. Rose, Victorian America and the Civil War (New York: Cambridge University, 1992), 57-63.

${ }^{18}$ John J. Burke to Newton D. Baker, August 13, 1918, folder 3, box 5, National Catholic War Council Records.

${ }^{19}$ John J. Burke to Newton D. Baker, July 17, 1918, appended to "Minutes of a Meeting of the Executive Committee of the General War-Time Commission of the Churches," September 4, 1918, folder 11, box 70, Federal Council of the Churches of Christ in America Records; "The Adjutant General's Report to the Third Assistant Secretary of War," July 25, 1918, appended to "Minutes of a Meeting of the Executive Committee of the General War-Time Commission of the Churches," September 4, 1918, ibid.
} 
discord. Yet, even the disagreements among its members are illustrative of the evolving nature of American religion during World War I. One issue arose when the committee assumed responsibility for apportioning chaplaincy positions among "the different religious beliefs," a task which required addressing the vexing problem of protestant denominational division. John Burke lamented that "the Protestant sects" created the biggest problem for committee members. Not only did the group have to contend with the broad divisions that separated protestants, Catholics, and Jews from one another, but there were also the smaller cleavages that divided Episcopalian from Methodist, and Baptist from Presbyterian. ${ }^{20}$

The Federal Council of Churches was established precisely for the purpose of overcoming such differences, and its leadership helped to smooth over protestants' divisions during the war. But joint endeavors with Catholics and Jews raised the new question of how to negotiate the relationship between a divided protestantism and a comparatively united Catholicism and Judaism (to be sure, there were divisions in both; but the leaders of both traditions who were actively involved in supporting the war effort tended to speak with greater unanimity). The problematic issue was whether Catholicism and Judaism should be viewed as "denominations," which suggested parity in status to individual protestant sects, or as faith traditions, the equivalent not of individual protestant denominations but rather of protestantism as a whole.

This very question had already arisen in the context of determining the membership of the Committee of Six. Two Protestant members, William Adams Brown and Robert Speer, forcefully advocated the addition of Methodist and Baptist clergymen to the committee in an effort to, as Burke described it, "command the following of all the Protestant bodies." But the Catholic priest objected, believing it impossible "to have anything like a numerical representation of all the Protestant bodies else the whole purpose of the Committee will be defeated." Other members, including John Mott and Harry Cutler, shared this assessment that having representatives of all the major protestant churches would make the committee too unwieldy. Brown and Speer acquiesced to the wishes of the majority. While protestantism as a whole was well represented in the group, individual denominations - even large ones - could not expect the appointment of one of their own. The membership of the Committee of Six was therefore defined in terms of faith traditions rather than particular denominations. ${ }^{21}$

\footnotetext{
${ }^{20}$ Burke to Prendergast, November 10, 1917, folder 5, box 5, National Catholic War Council Records.

${ }^{21}$ John J. Burke to Harry Cutler, November 10, 1917, January 2 1918, folder 9, box 5, National Catholic War Council Records.
} 
While this debate about whether Catholicism and Judaism were akin to denominations or faith traditions was solved by the committee with relatively little ill-will, this question proved more contentious in the larger context of military policy. The representation of individual protestant denominations relative to Catholics and Jews was at the heart of one of the most headed debates of the war. During the months that elapsed between the army's initial conscription of troops and the enactment of legislation creating the military chaplaincy, local clergy from the communities surrounding army camps stepped in and provided pastoral care to soldiers. The War Department never entirely approved of this solution, preferring that only trained chaplains perform such ministerial functions. When the chaplaincy corps was established, Newton Baker prohibited local clergy from working in the camps. In an apparent attempt to deflect criticism, he announced that the Committee of Six supported the complete exclusion of these local ministers. $^{22}$

This shift in War Department policy deprived many protestant denominations of representation in military camps. Under the old system, all local ministers enjoyed access, meaning that Baptists, Presbyterians, Episcopalians, Methodists, and members of other denominations felt that their form of protestant Christianity was represented. The new policy consolidated the task of ministering to protestant soldiers under the aegis of organizations encompassing all protestant traditions, such as the YMCA. This change infuriated some denominational leaders. The editors of a Baptist periodical expressed their outrage that "the ministers of the gospel representing the various Christian denominations are to be excluded from the camps, while the priests of the Roman Catholic Church will continue to use the elaborate ceremonials of Romanism." These editors had equal contempt for Jews, and they blamed the Committee of Six for the entire situation. Sarcastically noting their "admiration for the adroitness and efficiency of our Roman Catholic and Jewish friends," they lamented that "the Romanist and the Jew walk away with every privilege" while "the four eminent Protestants of the committee seem to have no influence whatever!",23

Beyond revealing that inclusive sentiments were far from ubiquitous in the United States during World War I (though one subscriber did chide the editors for their incessant "pounding away at Catholics and Jews" and urged that it was time "for such narrowness and intolerances to cease"), the

\footnotetext{
${ }^{22}$ William Adams Brown to Frederick P. Keppel, September 5, 1918, folder 6, box 5, National Catholic War Council Records; Frederick P. Keppel to John J. Burke, September 10, 1918, ibid.; William Adams Brown to John J. Burke, Sept. 6, 1918, folder 8, box 5, ibid.

${ }^{23}$ "Must the Camp Pastors Go?," The Watchman-Examiner (September 26, 1918), clipping in folder 6, box 5, National Catholic War Council Records; "Catholics, Jews, Camps, and War Chests," The Watchman-Examiner (Oct. 13, 1918), clipping in ibid.
} 
objections raised by these Baptists reveal how the war forced Americans to interrogate their religious categories. The protestants on the Committee of Six, who embraced the ecumenical outlook that increasingly defined the mainline denominations, were satisfied provided that some form of protestantism had representation in the camps. But other protestants, especially those who were less enamored with ecumenism-let alone interfaith comity-disagreed. They insisted on viewing Catholicism and Judaism as the analogs to individual denominations, not to protestantism as a whole. "If Roman Catholic priests and Jewish rabbis are allowed in the camps, why not Baptist preachers?" they asked. In their view, if the "distinctive bodies" of Judaism and Catholicism were "recognized by the Government and welcomed to the camps," so too should the clerics of Baptist churches and other denominations. ${ }^{24}$

Despite pressure from certain protestant churches, the War Department did not relent. Individual protestant denominations received no guarantee of representation at military facilities. One of the clear consequences of World War I, then, was that the federal government began to view the nation's religious landscape as something akin to the Committee of Six. Protestantism continued to enjoy the privileges that came with its history as the nation's dominant religion, but its individual denominations did not. Consensus emerged, meanwhile, that Catholicism and Judaism represented faith traditions equal in stature to protestantism.

Beyond the critical role that it played in shaping how influential Americans conceived of Catholicism and Judaism, the Committee of Six was instrumental in addressing other controversies, including two surrounding the insignia displayed on the chaplains' uniforms. The first arose when War Department officials decreed that chaplains would not wear rank insignia, believing they would function better if they were not clearly situated within the military hierarchy. Soon after, Robert Speer received a telegram signed by "two hundred fifty chaplain candidates representing Catholic Protestant and Jewish faiths" who protested the change and urged that "every influence be used to remove this injustice and repair this wrong." The idea that interfaith cooperation led to more tangible results was clearly not limited to members of the Committee (though these trainees, whose protest was considered "gross insubordination," did not find their request granted). ${ }^{25}$

\footnotetext{
24“"Catholics, Jews, Caps, and War Chests"; on the centrality of ecumenism in early-twentiethcentury mainline protestantism, see David A. Hollinger, After Cloven Tongues of Fire: Protestant Liberalism in Modern American History (Princeton, N.J.: Princeton University, 2013), xiii-xiv; Matthew S. Hedstrom, The Rise of Liberal Religion: Book Culture and American Spirituality in the Twentieth Century (New York: Oxford University, 2013), 35-39.

${ }^{25}$ Robert E. Speer to John J. Burke, September 26, 1918, folder 14, box 5, National Catholic War Council Records; John J. Burke to Robert E. Speer, September 29, 1919, ibid.
} 
A second debate concerning insignia had greater potential to inflame tensions. While chaplains were prohibited from displaying symbols of rank, they did receive a distinctive insignia - the cross - that identified their role as military clergy. When the Jewish representative on the Committee of Six, Harry Cutler, protested on behalf of his co-religionists, the War Department announced that the cross would be replaced by a shepherd's crook as the insignia for all chaplains. This decision drew the ire of Catholics and protestants, who protested that any religious symbol besides the cross "would be meaningless." Ultimately, a compromise was reached: Christian chaplains would continue to wear the cross, while Jewish chaplains would receive their own insignia. After considering a range of options that included "a burning bush," "an altar," and a "seven-branch candlestick," the War Department agreed to the Star of David (provided it was designed in such a way as to avoid any "real or fancied resemblances" to the star worn by military generals). ${ }^{26}$

In practical terms, the insignia debate had a minor impact, as fewer than a dozen Jewish chaplains served during World War I. The controversy nevertheless highlights the extent to which members of America's dominant religious traditions - in this case both Catholics and protestants togetherwere willing to accommodate the Jewish minority. On the one hand, the five Christian members of the Committee of Six betrayed their complete unwillingness to relinquish any privilege of their status. "The christians [sic] are in a very large numerical majority and by rule of democracy have a right, so long as they do not infringe on the rights of others," John Burke told the Secretary of War, to wear "their own symbol." On the other hand, Burke was determined both to ensure that Jews were not forced to wear a Christian symbol and to see that no blame came to Jewish leaders for the War Department's plan to abolish the cross altogether. Noting that "the Jews joined most heartily" in seeking to restore the cross as the insignia for Christian chaplains, Burke affirmed that they were "decidedly in favor" of "Christian chaplains wearing the cross." 27

For its part, the War Department gave consent to different insignia for Jewish chaplains. One official reported that the Secretary of War had "no objection whatever to the slight lack of uniformity" that the solution entailed. The insignia decision captured the shift in American culture on the home front during World War I. While Christians - spoken for by a Roman Catholic, not

\footnotetext{
${ }^{26}$ Harry Cutler to John J. Burke, September 6, 1918, folder 11, box 5, National Catholic War Council Records; John J. Burke to Newton D. Baker, June 28, 1918, folder 3, box 5, ibid.; Simon Jacobsen to Harry Cutler, April 27, 1918, folder 9, box 5, ibid.; K.P. Keppel to Harry Cutler, July 19,1918 , folder 10 , box 5 , ibid.

${ }^{27}$ Burke to Baker, June 28, 1918, folder 5, box 3, National Catholic War Council Records; John J. Burke to Richard H. Tierney, August 24, 1918, folder 5, box 5, ibid.
} 
a protestant-refused to give up majority privilege, they were willing to sacrifice uniformity in order to respect the nation's religious diversity. ${ }^{28}$

\section{Interfaith Wartime Efforts in the United States}

The Committee of Six was far from the only model of interfaith cooperation during World War I. Instances abounded of similar interaction, which often occurred in military settings without the committee's involvement. In 1917, the War Department established Camp Upton in Yaphank, New York, as a facility for training and housing soldiers before they departed for Europe. Because there were no churches or synagogues in the sparsely settled section of Long Island where it was located, the religious needs of the soldiers had to be provided for at the camp. Five protestant denominations committed the funds to construct a chapel, but plans called for the building "to be open for the use of the Roman Catholics and the Jews." 29

The organization and operation of the Camp Upton chapel exemplified how certain aspects of the relationship between American protestants and their Catholic and Jewish neighbors had changed and how others had not. Protestant leaders clearly believed that they controlled the chapel and that only through their generosity should Jews and Catholics gain access to the space. Moreover, their motives in extending the invitation to use the chapel were not entirely altruistic. The protestants responsible for the chapel's construction noted their desire to grant the Jewish Welfare Board's wish to have a place for Sabbath services and "private prayer." Their "offer of the use of the chapel to the Jews," however, was accompanied by the not-subtle suggestion that Jewish "financial cooperation" in its construction "would be welcome." Money, it turned out, could provide a powerful incentive for inter-religious harmony. ${ }^{30}$

Despite the clear assumption of protestant superiority and mixed motives that underlay the decision to offer use of the chapel to Catholics and Jews, the completed worship space at Camp Upton became an exemplar of religious coexistence. The service of dedication for the chapel opened with a Catholic priest offering an invocation and included prayers led by Episcopalian and Presbyterian ministers before concluding with a benediction proclaimed by a Jewish rabbi. Almost immediately, the building

\footnotetext{
${ }^{28}$ Keppel to Cutler, July 29, 1918, folder 10, box 5, National Catholic War Council Records.

29 "Minutes of the Meeting of the Committee on Inter-Church Buildings," February 6, 1918, folder 13, box 70, Federal Council of the Churches of Christ in America Records; "Minutes of the Meeting of the Committee on Camp Neighborhoods," November 28, 1917, folder 8, box 70, ibid.

30"Minutes of the Meeting of the Committee on Inter-Church Buildings," February 6, 1918, folder 13, box 70, Federal Council of the Churches of Christ in America Records.
} 
became a bustling center of religious activity, "in use not only by the protestants, but also by the Catholics for their confession and the Jews for their Friday evening service." 31

Among civilians, interfaith cooperation in support of the war effort also became commonplace. This, too, resulted from a mix of idealistic and pragmatic motives. Soon after American entry into the conflict, one prominent protestant clergyman urged Herbert Hoover, the recently appointed head of the United States Food Administration, to specifically target Catholics in his campaign of rationing, "not only because of their numbers, but also because the food supply in the homes of the rich is largely under the control of Roman Catholic servants." Hoover heeded this advice. In launching his food program, he immediately sought support from Methodists, Presbyterians, Episcopalians, Jews, and Roman Catholics. ${ }^{32}$

Cooperation in support of Hoover's food program presaged the broader interfaith activity that emerged later in 1917, when the GWCC sought to include "all Protestant, Catholic, and Hebrew churches" in "the Christmas campaign of the Red Cross." Once again, the complexities of Americans' self-understanding at this moment are apparent. There is clearly something discordant about an attempt to enlist non-Christians in a Christmas fundraiser, and it is quite likely that Jews recoiled at the suggestion that they were just another "church." Yet, beneath the lingering elements of a hegemonic protestant culture, the 1917 Red Cross campaign revealed feelings of shared purpose among protestants, Catholics, and Jews at the grassroots level. Contemporary reports noted that "pastors, priests and rabbis not only spoke before their congregations but thousands of them joined the staffs of speakers" that traveled widely. Indeed, this interfaith campaign highlighted the relative weakness of American protestantism in an unanticipated way. When monetary contributions from their own churches fell short of the projected amount, protestants were left to watch sheepishly as Catholics and Jews made up the difference. ${ }^{33}$

The Red Cross Christmas campaign typified the growing sentiment that religious differences proved insignificant when compared to the needs of the

\footnotetext{
31"“The Church and the War," Outlook 118, no. 17 (April 24, 1918): 664; "Minutes of the Meeting of the Executive Committee of the General War-Time Commission of the Churches," March 6, 1918, folder 10, box 70, Federal Council of the Churches of Christ in America Records.

${ }^{32}$ Charles H. Brent to Herbert Hoover, June 13, 1917, folder, box 14, Brent Papers; William Adams Brown, "General War-Time Commission of the Churches: Its Organization and Its Purpose" (New York: The General War-Time Commission, 1917), 7.

${ }^{33}$ Worth Marion Tippy, The Church and the Great War (New York, 1918), 20-21; "Minutes of a Meeting of the Executive Committee of the General War-Time Commission of the Churches," November 21, 1917, folder 9, box 70, Federal Council of the Churches of Christ in America Records; "Minutes of the Annual Meeting of the General War-Time Commission of the Churches," September 24, 1918, pp. 121-122, folder 11, box 70, ibid.
} 
nation at large. In Arlington, Massachusetts, the town's Catholic and protestant churches banded together to collect funds for the war effort. One Congregationalist minister noted that at an event in support of the Red Cross campaign, "every clergyman in Town was on the platform - two Catholic priests, and an Episcopalian, and a Methodist minister" all addressing a crowd "made up of Catholics and Protestants" who were "glad that something brought them together." 34

A comparable fundraising endeavor occurred in Connecticut, where the Catholic Knights of Columbus invited the pastor of a Congregational church to give the keynote address at a fundraiser for their war work. Despite the fact that the "entire audience was composed of Catholics," this protestant clergyman found that his appeal for money led him into a moment of shared worship. When the priest began a prayer, he noted "we all kneeled, and altho' part of the prayer was to Mary I said "Amen." A few decades earlier, the prospect of a protestant clergyman affirming a prayer to Mary would have seemed to many New England Congregationalists a fate worse than military defeat. ${ }^{35}$

There were other instances of interfaith worship. Soon after the United States entered the war, the religious communities of Cincinnati organized a rally, at which numerous Christian and Jewish clergy spoke. Among these was the rabbi David Philipson, who insisted that "differences of creed" did not matter in times of war. He told his audience, "whatever be our separate beliefs, and whatever be the churches we attend, we remember only one thing now, and that is that we are all one as the children of God-all one as citizens of this great republic." Several months later, one of the largest examples of wartime interreligious worship occurred, as 4300 people representing eighty-six Christian churches and two Jewish congregations thronged to the Convention Hall in Rochester, New York, for a Thanksgiving Day service. ${ }^{36}$

\section{Over There: Exporting the InTERfaith IdeAl to Europe}

These efforts to foster interfaith cooperation and understanding at both the institutional and grassroots levels ensured that the view of protestants, Catholics, and Jews as fully included participants in national life had become firmly established by the time large numbers of troops were deployed in

\footnotetext{
${ }^{34}$ Samuel Bushnell to Newman Smyth, Dec. 20, 1917, folder 1, box 1, Newman Smyth Papers, Yale University Library Manuscripts and Archives, New Haven, Conn.

${ }^{35}$ Charles Dinsmore to Newman Smyth, December 10, 1917, folder 15, box 1, Smyth Papers.

${ }^{36}$ David Philipson, “America's Entrance into the War" (1917), reprinted in Centenary Papers and Others (Cincinnati, Ohio: Ark Publishing Company, 1919), 301; William A.R. Goodwin to Charles H. Brent, December 1, 1917, December 1917 folder, box 14, Brent Papers.
} 
early 1918. One of the strongest proponents of this perspective was Charles $\mathrm{H}$. Brent, the Canadian-born Episcopalian who had spent the better part of two decades as a missionary to the Philippines. In 1917, Brent was elected the bishop of Western New York. On his way back to the United States, he detoured to Europe for what was supposed to be a brief period of work for the YMCA. At the urging of General John Pershing (the two had known each other in the Philippines, where Pershing had served during PhilippineAmerican War), Brent reluctantly agreed to serve as the chief of the new chaplaincy corps. His appointment was widely cheered by protestant Americans, and the decision to appoint a Catholic as Brent's deputy assured the support of Roman Catholics as well. ${ }^{37}$

In France, interfaith cooperation among chaplains became widespread, in part because of Charles Brent's commitment to the ideal. The bishop admired the Committee of Six for its encouragement of "coordination" among religious bodies, which he believed represented a crucial ingredient to "mutual understanding." Brent sought to incorporate that spirit into his own work. But this cooperation also reflected necessity. Units were not religiously uniform, which made it impossible to guarantee that individual soldiers had contact with a chaplain from their particular tradition. Moreover, the chaos of life in a war zone made matters worse. An exasperated Brent lamented that the situation "would have been ludicrous if it had not been exasperating." The lack of sufficient Jewish chaplains was particularly acute throughout the war, and matching Catholic clergy to predominantly Catholic units proved a near impossibility. In one instance, Brent noted, a regiment was assigned a Roman Catholic a chaplain - despite the fact that of the 2000 men in the unit, a mere " 40 or 50 or 60 " were Catholics. ${ }^{38}$

The necessity of cooperation inspired Brent "to promote . . . a sense of brotherhood among the Chaplains" and to foster "that spirit of respect for one another's convictions that will make it possible for men to work side by side in a common cause." At the chaplaincy headquarters, Brent prohibited his subordinates from creating denominational fiefdoms in which they might oversee chaplains of their own tradition. He insisted that the purpose of chaplains was "to minister to the needs of others irrespective of their religious affiliation, as though they were our own." Only by doing so would

\footnotetext{
37"Minutes of the Joint Committee on Chaplains," January 28, 1918, folder 9, box 70, Federal Council of the Churches of Christ in America Records; on Brent's career and involvement with government officials, see Ian Tyrrell, Reforming the World: The Creation of America's Moral Empire (Princeton, N.J.: Princeton University, 2010), 191-202.

${ }^{38}$ Charles H. Brent to Cameron J. Davis, August 10, 1918, August 1918 folder, box 15, Brent Papers; "Minutes of the Informal Conference with Chaplain Brent at the Office of the Federal Council," February 14, 1919, folder 12, box 70, Federal Council of the Churches of Christ in America Records.
} 
each chaplain "look upon the conviction of his brother with the same respect as his own." Brent's efforts did not go unnoticed. The Jewish chaplain Lee Levinger credited his Episcopalian superior with modeling interfaith cooperation in the way that he seemingly "forgot his own affiliations in the interest of all religions alike." This sense of fraternity also manifested itself in casual settings. One clergyman recalled witnessing "a Jewish Rabbi singing the Rosary, accompanied on the piano by a Catholic priest," which he thought exemplified "the brotherly spirit" of the chaplains. ${ }^{39}$

Ultimately, the realities of the war zone required chaplains to do more than merely cooperate and show friendliness to one another. They also needed to function as spiritual guides to men from other traditions. John Mott, the head of the YMCA, noted without the slightest trace of indignation that his son was under the "spiritual care" of a Roman Catholic priest. What was true for the child of an extremely prominent protestant was equally true for other soldiers. The chaplain Chellis V. Smith, whose 1925 book Americans All described the war's interreligious camaraderie, insisted that "nowhere else on earth have clergymen worked so well together as in the army." Smith recalled with particular fondness "one of the most loved chaplains," the Catholic priest John De Valles, who once carried an injured protestant solider to safety. When teased for risking his own life to save a nonCatholic, De Valles reportedly quipped, "there is no distinction of creed or race; we are all Americans here." Observers in the United States heralded reports of religious divisions collapsing in Europe. The NCWC enthusiastically publicized chaplains' accounts of "the altogether admirable spirit of fraternity" among clergy "ministering to our soldiers." Their report noted that "Catholic chaplains ... are not merely looking to the good of the Catholic boys, nor the Protestant to that of the Protestant boys. Each is working for the best interest of every man." ${ }^{\prime 40}$

Such interactions helped to forge close bonds between soldiers of one religious background and chaplains of another. Charles Brent was once puzzled to discover a machine-gun battalion in which every single member claimed to be a Roman Catholic. Finding such a situation unlikely, he investigated. "The boys said," Brent recounted, "we had such a good

\footnotetext{
${ }^{39}$ Brent to Davis, August 10, 1918, August 1918 folder, box 15, Brent Papers; Charles H. Brent, "Final Report to the Adjutant General," April 26, 1919, 1920 Folder, box 16, ibid.; Charles H. Brent to Newman Smyth, April 14, 1919, folder 10, box 1, Smyth Papers; Levinger, A Jewish Chaplain in France, 141; "Copy of the Memorandum from the Commandant Army Chaplains School to Senior Chaplain, G.H.Q.," November 30, 1918, folder 6, box 5, National Catholic War Council Records.

40"'Report of an Informal Gathering of the Committee [of Six]," May 29, 1918, folder 16, box 5, National Catholic War Council Records; "Press Release of the National Catholic War Council," enclosed with Burke to Speer, December 17, 1918, folder 14, box 5, ibid.; Chellis V. Smith, Americans All: Nine Heroes Who in the World War Showed That Americanism is above Race, Creed, or Condition (Boston: Lothrop, Lee \& Shepard, 1925), 26-27.
} 
chaplain and we were afraid you would take him away from us. He is a Roman Catholic and so we said we were Roman Catholics, and for the duration of the war we are Roman Catholics." Not only had their interactions with a priest cured these soldiers of any anti-Catholic animus that they might have brought with them to Europe, but they had also inspired a distinctly favorable disposition to Catholicism. ${ }^{41}$

Though not all soldiers went so far as to temporarily assume a new religious identity, many did avail themselves of opportunities to participate in the worship services of a tradition other than their own. Sometimes, this was because religion trumped boredom. Lee Levinger was surprised to arrive at a service to discover the appointed space "crowded with men of every type" in numbers far exceeding the Jewish population of his regiment. He learned that the service was held in the camp's only common space and the troops "came there every night for the show, movie, or service which might be provided." But the non-Jews in attendance did not treat the event as a mere spectacle. Rather, they displayed an interest that went beyond being "merely respectful." As the war progressed, such occurrences became common. Levinger recounted that non-Jews typically represented anywhere from ten to eighty percent of attendees at his services. ${ }^{42}$

Not all instances of common worship were spontaneous. Often, interfaith participation in religious services was planned. This not only reflected the widely held view that the war effort benefited from feelings of close comity among protestants, Catholics, and Jews, but it also conveyed to soldiers that military leaders treated the three faiths equally. Levinger invited a Methodist chaplain to give the sermon on the second day of the Jewish New Year, and the rabbi himself eagerly attended the Roman Catholic midnight mass on Christmas Eve in 1918. He reported that "every chaplain with whom I have compared notes has told me of similar experiences." His observation was borne out by Charles Brent, who took part in a Rosh Hashanah celebration where he spoke to a large crowd of Jewish soldiers. Likewise, the president of the Federal Council of Churches reported attending a service in Europe "conducted by a group of Protestant chaplains, attended by the generals and their staffs and a multitude of officers and soldiers who came, apparently, more or less irrespective of their religious faith." This protestant clergyman made particular note of the attendance of four Catholic generals, who displayed "a very devotional spirit."

\footnotetext{
${ }^{41}$ "Minutes of the Informal Conference with Chaplain Brent."

${ }^{42}$ Levinger, A Jewish Chaplain in France, 23, 155.

${ }^{43}$ Ibid., 138; Charles H. Brent Diary, September 6, 1918, Brent Diary May 20, 1918 to August 24, 1919, box 3, Brent Papers; "Remarks by Charles S. Macfarland at the Second Annual Meeting of the General War-Time Commission of the Churches," September 24, 1918, folder 11, box 70, Federal Council of the Churches of Christ in America Records.
} 


\section{Transatlantic Comparison: American Liberalism vs. EUROPEAN ORTHODOXY}

It was no coincidence that efforts to define America's religious culture occurred in the context of the nation's participation in a European war. In addition to bringing protestant, Catholic, and Jewish Americans into closer contact through military service and coordinated campaigns to support the war effort, entry into the conflict brought a new degree of contact with European culture. Large numbers of Americans had the opportunity to witness firsthand the state of religion in France and Britain. Drawing such contrasts helped to cement their commitment to the religious ideals that underlay the growing expressions of commonality among members of America's three major faith traditions.

One obvious impetus for the sense of shared purpose among American protestants, Catholics, and Jews was the frequent casting of the war as a fight between the forces of good and evil. In this rhetoric, the pious United States stood opposed to a godless Germany. The differences separating Judaism and the various branches of Christianity from one another paled in contrast to the larger conflict between one society that was heavily religious and another that seemed given to a materialistic militarism. ${ }^{44}$

While Woodrow Wilson's propaganda machine sought to draw attention to the irreligion of America's enemy, religious leaders were far more interested in contrasting the vibrancy of Americans' faith with the seemingly sapped vitality of belief among the nation's allies. In Britain, the population suffered from what many observers believed to be a state of apathy, which had negative repercussions for national morale during the war. A correspondent of GWCC president Robert Speer bewailed the exposure of "the evil that is being done ... by the low tension type of Christianity that has prevailed in our churches." The perceived problem of immorality in France, which had initially drawn the concern of American religious leaders, was believed to stem from the decline of Christian influences there. At the outset of the war in 1914, even before American entry, future Committee of Six member John Mott observed that "tens of millions of people in France" were "as much without Christ as the tens of millions whom I mingled with in India, in the heart of Africa, in the inland provinces of China or in the Turkish Empire." The result of this, he predicted, would be "moral collapse." Similarly, an observer told Speer of the "vast and terrifying problem" that Christianity faced in France and suggested that the state of religion and morals had "long

\footnotetext{
${ }^{44}$ For a useful analysis of how protestants in particular cast the war against Germany in the framework of good vs. evil, see Andrew Preston, Sword of the Spirit, Shield of Faith: Religion in American War and Diplomacy (New York: Knopf, 2012), 253-263.
} 
since gotten beyond the control of men." The apparent ubiquity of venereal disease and prostitution in the war zone seemingly provided ample evidence of the sapped state of religion in Europe. ${ }^{45}$

When Americans abroad reflected on the state of religion in France, they grew convinced of the superiority of their society. In the United States, they argued, the very definition of religion itself was expansive enough to encompass protestants, Catholics, and Jews of various theological outlooks. By contrast, Lee Levinger noted that "religion to most people in France means orthodoxy," which precluded the more liberal views of religious difference that provided the basis for comity in the United States. "Those large groups of liberals who in America would be adherents of liberal movements, Jewish or Christian, in France are usually entirely alienated from religion," he wrote. Levinger recounted meeting a young French priest, who expressed incredulity that protestants, Jews, and Catholics all held leadership positions in the American chaplaincy corps. "As a Frenchman it was hard for him to understand the kind of religious liberty which means cooperation and friendship," the rabbi observed. In France, "religion" connoted "domination" and "the curtailment of liberty," whereas liberty was equated with "hostility and intolerance of religion." 46

In reality, the French also favored cooperation, and they, too, drew upon stories of interreligious understanding - including the seemingly ubiquitous example of a rabbi holding a crucifix for a dying Catholic - to emphasize their conviction that differences of faith mattered little during the war. Yet, Levinger's basic assessment was correct. As the French writer Maurice Barrès noted in a book that was translated into English and heavily shaped American perceptions of religion in France, protestantism, Catholicism, and Judaism were viewed as entirely different systems that had been bridged out of political necessity. Whereas many American religious leaders claimed that the war revealed an essential unity and commonality among the three traditions, the French still saw fundamental division. Barrès noted, for example, that because "rigid morality" characterized the "intensively logical" protestantism, it was closer to a "philosophy" rather than the more "emotional" Catholic "religion." It was just these sorts of distinctions about what was and was not a "religion" that many Americans thought they had put behind them. All "religious faiths," noted one American commentator of Barrès's work, came together "in resistance to the German paganism.",47

\footnotetext{
${ }^{45}$ Speer, "Opening Address of the General War-Time Commission of the Churches"; John R. Mott, "World Interest in the Evangelization of France" (1914), published in Addresses and Papers, Volume VI (New York: Association Press, 1947), 280.

${ }^{46}$ Levinger, A Jewish Chaplain in France, 67, 143.

${ }^{47}$ Maurice Barrès, Faith of France: Studies in Spiritual Differences and Unity, trans. Elisabeth Marbury (Boston: Houghton Mifflin, 1918), 61, 88-89; Henry Van Dyke, "Relief of Protestant
} 
Levinger's invocation of religious liberalism spoke to one additional ingredient that proved crucial for the interfaith cooperation during World War I: nearly all of the active participants in such efforts represented the liberal branches of their respective traditions. Charles Brent, Robert Speer, William Adams Brown, and many of the other protestant leaders active in the GWCC had embraced theological liberalism, with its affirmation that religious beliefs might be modified to reflect modern thought and culture. Both Lee Levinger and Harry Cutler were Reform Jews, and their tradition likewise had long encouraged adaptation of some practices to contemporary culture. Liberalism in Catholicism was a touchier subject by the start of World War I, as papal encyclicals in 1899 and 1907 had signaled the Vatican's disdain for anything that resembled religious accommodation to cultural values. Yet the influence of liberalism could be seen in John Burke. The head of the NCWC and chairman of the Committee of Six was a priest in the Paulist order, which had been established by Isaac Hecker, one of the intellectual forebears of liberal Catholicism in the United States. ${ }^{48}$

Given the immense cultural authority that protestants still wielded, it was their movement toward theological liberalism that proved most significant. In the decades before the war, as liberals gradually assumed positions of leadership in most of America's major denominations, they honed a religious message that emphasized common action for the betterment of society in order to bring the "kingdom of God" to earth. A corollary to this social focus was an effort to minimize doctrinal differences. One consequence of protestants' new social focus and pared-down theology was that it ultimately served to minimize differences with Catholics and Jews as well. Even before the war, Jewish and Catholic observers claimed feelings of closer sympathy with protestantism as a result of its new outlook, and leading protestants emphasized that a "unity of faith already exists" because "Jews and Christians" agreed with them on the essential "articles of faith." 49

\footnotetext{
Churches in France and Belgium,” June 1, 1919, folder 14, box 3, Henry Van Dyke Papers, Presbyterian Historical Society, Philadelphia, Pa.

${ }^{48}$ On the emergence of liberal theology as the dominant force in protestantism during the decades before World War I, see Gary Dorrien, The Making of American Liberal Theology: Idealism, Realism, and Modernity, 1900-1950 (Louisville, Ky.: Westminster John Knox, 2003), 21-43; on Reform Judaism's accommodationist tendencies, see Jonathan D. Sarna, American Judaism: A History (New Haven, Ct.: Yale University, 2004), 124-132; on liberal Catholicism see Jay P. Dolan, In Search of an American Catholicism: A History of Religion and Culture in Tension (New York: Oxford University, 2002), 99-117.

49"“The Unity of the Faith," Outlook 95, no. 7 (June 18, 1910): 336-337; David Philipson to Charles H. Brown, June 22, 1916, folder 1, box 1, David Philipson Papers, Jacob Marcus Rader Center of the American Jewish Archives, Cincinnati, Ohio; "Talk About New Books," Catholic World 57 (August 1893): 722; on the reworking of liberal protestant theology, see Dorrien, The Making of American Liberal Theology, 57-62.
} 
During World War I, this turn toward a more simplified religious outlook closely aligned with the perception that the realities of war necessitated a straightforward message. Charles Brent insisted that "religion in its old conventional form has not enough hardihood to continue its existence in the battle line" and argued that a "religion of Jesus Christ in a simpler form" was needed. The Baptist minister Robert Ashworth likewise averred that "religion in the trenches is religion stripped bare of its accessories and trimmings." Religious experience consisted solely in the relationship between "the soul and God" and was therefore a matter of "experience" rather than of "creed." Many Catholics and Jews agreed, and they likewise modified their practices. The priest Francis Duffy recounted that before a battle, he held a "silent prayer meeting" in which soldiers "stood around me in a rough semi-circle, caps in hand and heads bowed, each man saying his prayers in his own way." Duffy noted that he found "this simple ceremony much more effective than formal preaching." So, too, the rabbi Lee Levinger reported that "religious ideas and practices had to satisfy" the "immediate needs" of the typical solider, while "theological concepts . . . meant nothing to him practically." Another prominent rabbi, meanwhile, summed up the war's effect on theology. In the heat of conflict, he declared, "Protestant, Catholic, Jew forgot their theological differences" as "the dross of baser human passions was burned away and the pure gold of the divine likeness, which links all together as children of the one father, issues forth from the crucible."50

Certainly protestants, Catholics, and Jews could agree to being "children of the one father," but when the focus turned to Jesus, matters became more complicated, especially for interactions between Christians and Jews. Yet, here too, theological innovations by Christians - and particularly by protestants - made things easier. Wartime depictions of Jesus emphasized a more human figure whose identity was less bound by questions of divinity. In part, this shift reflected the growing popularity of "muscular Christianity" in American protestantism, which offered a simpler outlook that downplayed doctrinal questions about the precise nature of Jesus's divinity in favor of an emphasis on his masculinity. The depiction of Jesus as an active, virile man - Charles Brent's "simpler form"-made the central figure of Christianity more relatable to Jews. Such views were transmitted to soldiers as well. A poem in the military newspaper The Stars and Stripes noted that chaplains did not "pull no highbrow stuff," but rather focused on Jesus as "the First

\footnotetext{
${ }^{50}$ Charles H. Brent to George W. Perkins, April 30, 1918, April 1918 folder, box 15, Brent Papers; Robert A. Ashworth, "Christian Union After the War," The Biblical World 52, no. 3 (November 1918): 292; Francis P. Duffy, Father Duffy's Story: A Tale of Humor and Heroism, of Life and Death with the Fighting Sixty-Ninth (New York: George H. Doran, 1919), 233; Levinger, A Jewish Chaplain in France, 206-207; David Philipson, "Man Made Differences and God Made Resemblances," Hebrew Standard 73 (June 16, 1919): 3.
} 
and bravest Christian." Debates about whether or not Jesus represented the messiah could be overlooked in favor of a shared appreciation of his human characteristics. $^{51}$

The shift to such a message did not come quickly or easily to many chaplains, regardless of their religious affiliation. One chaplain confessed to Charles Brent that he had found himself "much concerned" and "no little upset" by his inability to reach soldiers until he adjusted his approach "entirely" and began "to preach the simple gospel" of a "personal relationship" with Jesus. Ministers, priests, and rabbis alike struggled at times to ignore their impulse to emphasize doctrinal nuance. This, too, provided the basis for shared experience by leveling the playing field for rotestants, Catholics, and Jews. By virtue of their considerable cultural authority, American protestants had historically not often needed to dramatically and rapidly adjust the core nature of their teaching. Catholics and Jews, by contrast, had long faced pressure to accommodate their beliefs and practices to dominant cultural values. On the battlefields of Europe, however, protestant chaplains found themselves in precisely the same boat as their Catholic and Jewish colleagues in having to accommodate their preferred teachings to the exigencies of circumstance. ${ }^{52}$

\section{Debating Religion and Ethnicity}

Despite the efforts during World War I to advance a conception of American society as one in which Jews and Catholics were equal participants with protestants, significant impediments existed that prevented reality from matching the ideal put forth by people like Charles Brent, Lee Levinger, and the members of the Committee of Six. Despite the dominance of liberals in many of the war organizations, conservative protestants made their presence felt. The editors of one conservative periodical grudgingly conceded that Catholicism as practiced in the United States was superior to Catholicism elsewhere, but they insisted this was "largely due to contact with Protestantism." These protestants insisted that they had "no desire to propagate" the Catholic faith "even at its best," and they likewise urged their co-religionists to "do all in their power to win Jews to Christ and Christianity."

\footnotetext{
51“As We Know Them: The Chaplain," The Stars and Stripes (March 8, 1918), 3; for a useful study of this phenomenon, see Clifford Putney, Muscular Christianity: Manhood and Sports in Protestant America, 1880-1920 (Cambridge, Mass.: Harvard University, 2001), 42-43.

${ }^{52}$ John McCormick to Charles H. Brent, undated, 1919 folder, box 16, Brent Papers.

53"Catholics, Jews, Camps, and War Chests."
} 
The desire of some Christians to convert them was one problem that Jews faced throughout the war; outright anti-Semitism was another. Harry Cutler, the Jewish representative on the Committee of Six, reported that army camps featured entertainers "under the auspices of Young Men's Christian Association" who "caricature various nationalities," including "the Jewish people" with particular "vehemence and prejudice." Jewish leaders also observed that the YMCA periodical, Trench and Camp, occasionally printed stories that had "the propensity to incite anti-Semitic sentiment." In the case of one such article, YMCA leaders swiftly apologized. So, too, the Catholic priest John Burke was quick to declare his willingness to "make an official protest" when a Jewish soldier reported receiving a copy of the New Testament in Hebrew. But the frequency with which religious leaders found themselves responding to anti-Semitic statements and incidents highlights the elusiveness of full inclusion of Jews during World War I, the rhetoric of many influential Americans notwithstanding. 54

Moreover, even well-meaning protestants undercut their own good intentions, as when William Adams Brown recorded in the minutes of a Committee of Six meeting that nominations of possible chaplains would be made by "various Christian bodies." It took some gentle chiding from Harry Cutler to remind the Presbyterian theologian that the phrase "religious bodies" better reflected the presence of Jewish chaplains. In still other instances, protestants appeared not to grasp the uniqueness of Judaism. One 1918 census of chaplains consisted of only two categories: Catholics and protestants; Jews (along with Christian Scientists) were considered a subgroup of protestantism. ${ }^{55}$

While protestants were usually the source of the ill-will that belied efforts to eliminate religious animus, they were occasionally on the receiving end of such sentiments. Catholic workers at one army camp criticized protestant leaders in a manner that, in the words of one priest, brought "deepest shame." When a protestant woman was appointed head cook of the Catholic hospitality house at Long Island's Camp Mills, the Catholic attorney Virginia Mollenhauer objected. "It certainly was not unreasonable," she declared, to believe a Catholic woman would be hired for the job. Mollenhauer also accused the protestant cook - apparently without evidence - of being "intolerant of the

\footnotetext{
${ }^{54}$ Harry Cutler to William Sloane, October 3, 1918, folder 11, box 5, National Catholic War Council Records; Maurice H. Gelfand to the Jewish Welfare Board, September 27, 1918, ibid.; John J. Burke to Harry Cutler, June 25, 1918, folder 9, box 5, ibid.; William Sloane to Harry Cutler, October 4, 1918, folder 11, box 5, ibid.

${ }^{55}$ William Adams Brown to Harry Cutler, May 30, 1918, folder 9, box 5, National Catholic War Council Records; John J. Burke to Harry Cutler, June 25, 1918, ibid.; "Minutes of the Meeting of the Executive Committee of the General War Commission of the Churches," November 20, 1918, folder 11, box 70, Federal Council of the Churches of Christ in America Records.
} 
religious Beliefs" of Catholics, and she accused the camp commander of favoring the Protestant YMCA over Catholic organizations. When informed of her complaints, John Burke denounced Mollenhauer's "ugly words" and "un-catholic" tone. As in the cases of anti-Semitism, inclusiveness won the day with people in authority, but lingering debates revealed that such attitudes were not ubiquitous in American society. ${ }^{56}$

Indeed, these instances pointed to another obstacle to idealizations of an inclusive society: not all Catholic and Jewish Americans were eager to subscribe to the conception of the nation's identity advanced by military and government officials and their allies. Roman Catholics had an elaborate network of social institutions, and they proved reluctant to allow protestant and interfaith groups to have control over the religious life of their troops. Ceding such control, they felt, would invite attacks on essential elements of the faith or on Catholicism itself. With reports circulating of "alleged discrimination against Catholic sisterhoods in nursing," there was a strong impulse - especially among lay Catholics - to oppose cooperation with protestant organizations. Throughout the war, a feeling remained that protestant religious and military leaders dictated the terms of Catholic participation. ${ }^{57}$

So, too, many Jews held reservations about the model of religious cooperation advanced during World War I. Many of the leading supporters of the inclusive ideal put forward during the conflict were Reform Jews who subscribed to many of the same political and cultural values of their Protestant neighbors. There was, however, a large population of Orthodox Jews who had immigrated more recently and who were far less assimilated to middle-class culture. For them, the religious concessions demanded by leaders of the Committee of Six and the Chaplaincy Corps were not trivial. ${ }^{58}$

Indeed, the experience of Jewish Americans exemplifies just how thin a line existed between religious inclusion and discrimination during the war. On the one hand, the constant emphasis on similarity among protestantism, Catholicism, and Judaism represented a growing affirmation of commonality among traditions that would become the heart of the tri-faith ideal. But at the same time, this view could so minimize differences that its proponents disregarded as insignificant important aspects of Jewish belief and practice. In 1918, a Jewish soldier stationed at General Headquarters wrote to the editors of the weekly military newspaper The Stars and Stripes to request a chaplain for the "150 to 200 Jewish men" stationed there. The editors

\footnotetext{
${ }^{56}$ Virginia May Mollenhauer to Peter J. Muldoon, September 11, 1919, folder 1, box 5, National Catholic War Council Records; John M. Cooper to John J. Burke, September 30, 1919, ibid.; John J. Burke to Virginia May Mollenhauer, Sept. 27, 1919, ibid.

${ }^{57}$ Kerby to O'Connell, August 17, 1917.

${ }^{58}$ On this group of Orthodox Jews, see Sterba, Good Americans, 24-30.
} 
unsympathetically dismissed the request, and noted that "war conditions frequently make it impossible for a soldier to have provided for him the sort of service he was brought up in." Thus, they urged all troops to worship together "whether they be Catholics, Protestants, Jews or Christian Scientists," because "it is not the creed we worship, but God Almighty.",

In this single expression the editors of the popular newspaper showed the limits of the war's inclusive spirit. Just as the policies of the War Department and the Committee of Six had, to the annoyance of many evangelicals, collapsed protestantism into a single unity with no regard to denominational distinction, so, too, wartime leaders had likewise reduced Catholicism and Judaism to nothing more than worship of the God imagined by theologically liberally protestants. Such a view recurred time and again in wartime rhetoric. Other religious articles in The Stars and Stripes normalized religious practice as being identical to protestant worship, and the ideal chaplain was cast as a Christian clergyman who would tell soldiers "bout the Lord." 60

Beyond this failure to fully acknowledge important elements of belied and practice, the full embrace of Catholics and Jews as equal partners in American life was further hindered by the unwillingness of influential protestants to extend their inclusiveness to include cultural practices that did not appear religious. Condemnations of the habits of immigrants were widespread, as typified by a denunciation in the North American Review of the "potentially pernicious" failure of the United States "to assimilate" or "even to digest the great mass of aliens that has been received." President Woodrow Wilson was among the most prominent exemplars of such views, inciting crowds with attacks on "hyphenated" Americans. One of Wilson's most outspoken critics, the former president Theodore Roosevelt, shared his political rival's assertion that "the hyphen is incompatible with patriotism."

Religious leaders enthusiastically embraced the Americanization campaign, which complicated their rhetoric of interfaith comity. The Federal Council of Churches insisted that "the church as an agency must emphasize the spiritual and moral content of this program of Americanization." One element of this project centered on ensuring that immigrant populations in areas that produced industrial goods for the military remained under the influence of religious organizations. To accomplish this work, protestant leaders sought the help of Catholics and Jews. In these "war production communities"-

\footnotetext{
${ }^{59}$ Letter from Leo Simons, "War and the Faith," The Stars and Stripes (May 31, 1918), 4.

60" As We Know Them: The Chaplain."

61“"Americanizing America," North American Review 206 (October 1917): 519; Theodore Roosevelt, Fear God and Take Your Own Part (New York: Doran, 1916), 19; on Americanization campaigns, see Thomas J. Fleming, Illusion of Victory: America in World War I (New York: Basic Books, 2003), 65, 249-252.
} 
which included Gary, Indiana, and Erie, Pennsylvania - they arranged "a canvass of new families by all churches, Catholic, Protestant, and Hebrew." Protestants thus signaled their conviction that one could be fully Americanized without converting to their religious beliefs. When Theodore Roosevelt told a group of Roman Catholics in 1916 that to him "Americans" included "Jews and Catholics and Protestants," he put forward a view entirely aligned with that of leading protestants. ${ }^{62}$

Drawing clear distinctions between a person's religious identity and his or her cultural and ethnic characteristics proved difficult, however, especially in the case of Jews. In a pamphlet lamenting "an un-Americanized population," representatives of the Federal Council noted that New York had large Italian, Polish, Bohemian, and German populations but was also "the largest Hebrew city in the world." When protestants set out to acculturate "Hebrews," it was not entirely clear where ethnicity ended and religion began. Nor was it always easy to distinguish between the religious and cultural practices of Italian immigrants. Because of the overlapping character of various facets of an individual's identity, full inclusion of Catholics and Jews would require protestants to abandon their unbending insistence on acculturation. It would be several decades after World War I before most protestants reached such a point. ${ }^{63}$

\section{Limits, Aftermath, ANd Legacies of World War I}

During the 1940s, World War II would produce similar inclusive rhetoric, which in turn would inspire widespread acceptance of the United States as tri-faith country, best exemplified by Will Herberg's 1955 description of "Protestant, Catholic, Jew" America. But this did not happen following World War I. In the months and years after the armistice, the language of inclusion rapidly disappeared from public discourse for reasons including the weak foundation of such ideals, competing priorities among religious leaders, and a declining concern for projecting a certain vision of American civil religion to the rest of the world.

The idealization of protestant-Catholic-Jewish America that emerged during the 1940s and 1950s rested on a much stronger foundation than those of World

\footnotetext{
62"Leadership of the Church: In the Americanization of Foreign Speaking Peoples," (undated), folder 15, box 3, Federal Council of the Churches of Christ in America Records; "Social and Religious Conditions in Centers of Wartime Industries, Suggested Outline for Study and Organization," addendum to "Minutes of the Meeting of the Special Workers for Centers of War-Time Industries," April 24, 1918, folder 14, box 22, ibid.; Roosevelt, Fear God and Take Your Own Part, 358.

63،Advance Copy: "War-Time Americanization,"” undated, folder 15, box 3, Federal Council of the Churches of Christ in America Records.
} 
War I, which in part explains its resilience. It resulted from campaigns to emphasize interfaith "brotherhood" that grew widespread during the 1930s. In widely read religious literature and at public events in communities throughout the nation, protestant, Catholic, and Jewish leaders worked to foster inclusive sentiments. Thus, by the time World War II began and military officials once again sought to foster inclusiveness among soldiers, institutions existed to conduct efficiently the work that had been done haphazardly by the Committee of Six and chaplains during World War I. ${ }^{64}$

These campaigns of the interwar period had themselves resulted from the failure of their predecessors to prevent the rampant anti-Semitism and antiCatholicism that developed following World War I. Longstanding associations of Jews with political radicalism resurfaced as the consequences of the Bolshevik Revolution became apparent, and even some protestants who had eagerly espoused interfaith rhetoric during the war succumbed to anti-Jewish hostility. In 1919, the protestant minister and Princeton University professor Henry Van Dyke had told a crowd of Jewish Americans that "no religious creed" could claim preeminence in American life because "Jews, Catholics, and Protestants stand on the same basis." In a Christmas sermon three years later, his tone changed markedly, as Van Dyke denounced "the renegade, godless Jew" as "the most dangerous man in the world." Based on his other writings, it seems unlikely than Van Dyke viewed all Jews as godless. But he clearly believed that they represented the core proponents of an atheistic communism. Catholics fared somewhat better during the twenties, though they, too, suffered amidst the nativist rhetoric surrounding the immigration restrictions of 1924 and from the virulent anti-Catholicism that emerged during Al Smith's 1928 presidential campaign. ${ }^{65}$

The seeming inability for the inclusive ideology of World War I to militate against post-war anti-Semitism and anti-Catholicism highlighted the weak foundation on which the wartime rhetoric had rested. While leading liberal protestants had been emphasizing their commonality with Catholics and Jews since the late nineteenth century, few had attempted to popularize such

\footnotetext{
${ }^{64}$ On the specific language of "brotherhood," see Schultz, Tri-Faith America, 32-3, 35-41; Hedstrom, The Rise of Liberal Religion, 143-168; Benny Kraut, "A Wary Collaboration: Jews, Catholics, and the Protestant Goodwill Movement," in Between the Times: The Travail of the Protestant Establishment in America, ed. William R. Hutchison (New York: Cambridge University, 1989), 193-230; Benny Kraut, "Towards the Establishment of the National Conference of Christians and Jews: The Tenuous Road to Religious Goodwill in the 1920s," American Jewish History 77 (1988): 388-412.

${ }^{65}$ Henry Van Dyke, "Religion of Protestant Churches in France and Belgium," June 1, 1919, folder 14, box 3, Van Dyke Papers; Henry Van Dyke, "The World Needs Christmas," December 24, 1922, folder 15, box 3, ibid.; on post-WWI anti-Catholicism, see Dolan, In Search of an American Catholicism, 132-136; John T. McGreevy, Catholicism and American Freedom: A History (New York: Norton, 2003), 168-175.
} 
views widely in ordinary communities throughout the United States. Consequently, interfaith cooperation during the First World War depended on the particular characteristics of a specific historical moment, and rifts emerged among its most loyal champions even before the conflict ended. Whereas in 1917, Catholics, Jews, and protestants had banded together in support of a single Red Cross campaign, the following year brought two successive campaigns: the first for the YMCA/YWCA and other protestantled organizations, the second for the Knights of Columbus, the Jewish Welfare Board, and the Salvation Army. This plan drew scorn from people like Harry Cutler, who lamented that it "smacks too much of class distinction." Even among members of the Committee of Six, tensions that had remained in check during the war re-emerged in its aftermath. When William Adams Brown and other protestants produced a retrospective volume, The War-Time Agencies of the Churches, they made no mention of the committee. Nor did they acknowledge the contribution of Catholics, thus drawing the ire of John Burke. "You will remember," the priest chided Brown, "that in the compilation of our own handbook we submitted the page proofs to every one of the other churches." Disagreements like this helped to contribute to the sense that, despite the hope of its members to preserve its work in the postwar period, the Committee of Six by 1920 had become "moribund." $" 66$

Part of the problem was that the advocates of interfaith comity during World War I found themselves unsure where to channel their energies once the armistice had come and their immediate mission had vanished. All retained their broad commitments to expanding religion's moral influence and to diminishing discord and division, yet they differed in their conclusions for how to enact such goals. This was especially true of the protestants who had championed interfaith activity. Among the members of the Committee of Six, some, like Robert E. Speer and John R. Mott, turned their gaze away from shared work with Catholics and Jews and returned to their longstanding interest in foreign missions. Speer also increasingly adopted a language of Christian triumphalism that proved less inclusive of Jews. He described the League of Nations as "an indispensable and unavoidable implicate of all our Christian faith and endeavor in the world." 67

Those Americans who remained steadfast in supporting interfaith inclusion lacked an institutional home for their endeavors. To be sure, the military and

\footnotetext{
${ }^{66}$ Harry Cutler to Raymond Fosdick, August 15, 1918, folder 10, box 5, National Catholic War Council Records; William Adams Brown to John J. Burke, March 9, 1920, folder 8, box 5, ibid.; John J. Burke to William Adams Brown, March 12, 1920, ibid.; Harry Cutler to John J. Burke, June 29 , 1920 , folder 12 , box 5 , ibid.

${ }^{67}$ Robert E. Speer, The Gospel and the New World (New York: Fleming H. Revell Company, 1919), 29.
} 
related institutions continued to idealize the view of equality among protestants, Catholics, and Jews. The legislation to create a peacetime chaplaincy corps included a provision that its administration would consist of "three chaplains fairly representing the religious forces of the country." In 1934, when members of the Roosevelt administration sought to discuss "religious training" in military camps, they recognized the need to meet with "representatives of the Protestant, Roman Catholic, and Jewish faiths." The American Legion, which was the most prominent veteran's organization and which by the beginning of the 1930s boasted one million members, strove to include Catholics and Jews equally. Indeed, despite the overall conservatism of its political outlook, the Legion emerged as one of the strongest voices sustaining the interfaith ideal of the war. Noting that soldiers who fought in Europe "came back with a broader outlook," an editorial in the organization's periodical observed that "we may have been Protestants or Catholics or Hebrews; it made no difference." The Legion put its words into practice: its leader strongly denounced anti-Catholic attacks on Democratic presidential candidate Al Smith in 1928, and the following year the Legion appointed the rabbi Lee Levinger as its chaplain. ${ }^{68}$

But the nation's armed forces were scaled back following the armistice, and amid clamors for a "return to normalcy" they lacked the significance in national life that would allow them to encourage substantial changes to social values in the way that they would during the second half of the twentieth century. At the same time, many of the religious leaders most active in the war effort grew increasingly troubled by militarism and armed conflict. Few became outright pacifists, but many shared the views of William Adams Brown, who wrote in 1929 of the "needlessness" of death in World War I, especially "the loss of the lives" and "the loss of all for which these lives stood, and might have stood, in love, and trust, and kindly human friendship and international sympathy and cooperation." In such a context, it was difficult for religious Americans to grow excited about using military institutions to advance any cause, even a seemingly noble one like interreligious understanding. ${ }^{69}$

Yet, there was no obvious institution to assume the role that the military and federal government had played during the war in pushing-sometimes forcefully-the model of interreligious cooperation. The American Legion

\footnotetext{
${ }^{68}$ Gaylord S. White to Harry Cutler, December 5, 1919, folder 12, box 5, National Catholic War Council Records; "Addendum to the Minutes of the Meeting of the General Committee on Army and Navy Chaplains," September 20, 1934, folder 1, box 75, Federal Council of the Churches of Christ in America Records; "The Next Man's God," The American Legion Weekly 4 (March 31, 1922): 10; on Levinger and the American Legion, and the organization more broadly, see Ebel, Faith in the Fight, 172-190.

${ }^{69}$ William Adams Brown, Finding God in a New World: Sermons Preached at Home and Abroad (New York: Harper \& Brothers, 1929), 40.
} 
might have provided such a place, but its valorization of the military proved disconcerting to protestants with growing commitments to pacifism and internationalism. Some wartime religious leaders, including Brown and Charles Brent, shifted their attention to the international ecumenical movement. They believed that by lowering divisions within Christianity, they could eventually bring harmony between protestants and Catholics, not only in the United States but also throughout the world. Others, such as Brent and the Baptist clergyman Robert Ashworth, took leading roles in newly formed interfaith organizations. The most notable among these was the Committee on Goodwill between Jews and Christians of the Federal Council of Churches, which in the late 1920s helped to establish the National Conference on Christians and Jews (a group that would prove instrumental in advancing interfaith goals during World War II). But while these institutions preserved the tri-faith ideal that had been propagated during World War I, they lacked the focus and purpose the war had provided. Their activities were initially small in scale and centered on specific communities and college campuses, and organizers lacked opportunities to link their message of interfaith understanding to larger national concerns. ${ }^{70}$

But perhaps the greatest explanation for why the widespread inclusive efforts of World War I did not prove more resilient rests in how Americans viewed their relationship to the world during the 1920s. Much of the impetus for interfaith activity during the war grew out of a reconfigured conception of civil religion and a desire to project that ideal onto the world. In the minds of wartime leaders, the United States was a godly nation whose citizensprotestant, Catholic, and Jewish alike-were prepared to save a spiritually apathetic Britain and a morally sapped, irreligious France from the forces of a godless Germany.

Three decades later, a similar desire to contrast a tolerant, inclusive United States with Hitler's Germany would encourage the tri-faith ideal during World War II. Soon after, the Cold War battle of ideology with the Soviet Union would likewise foster the emphasis on a shared Judeo-Christian religiosity that Americans could project abroad as the antithesis to the perceived godlessness of communism. By contrast, religious bigotry came to be seen as socially corrosive and a tool by which the nation's enemies could undermine the unity and resolve of American society. ${ }^{71}$

\footnotetext{
${ }^{70}$ Dorrien, The Making of American Liberal Theology, 61-62; David Mislin, Saving Faith: Making Religious Pluralism an American Value at the Dawn of the Secular Age (Ithaca, N.Y.: Cornell University, 2015), ch. 6.

${ }^{71}$ Wall, Inventing the "American Way," 155-168.
} 
But in the immediate aftermath of World War I, there seemed little need for such an inclusive civil religion. The isolationism of the 1920 s meant that few Americans saw any need to proclaim their values abroad. Moreover, for the decade after World War I, there was no clear international ideological opponent that religious leaders seemed determined to fight. The indifference of the British and the immorality of the French posed little concern when the soldiers of those nations were no longer battlefield allies. Despite anxieties about irreligious Communism-typified by William Adams Brown's warning that "secularism, which was yesterday the creed of radicals here and there, has become a militant religion and has found a church in the Third International"- - few people in the 1920s saw a need to define an inclusive national religious identity that could be proclaimed both at home and abroad. Efforts to articulate a tri-faith civil religion would resume tepidly in the 1930s, before ultimately taking root during World War II and in the early Cold War. ${ }^{72}$

Still, the interfaith efforts of World War I were not in vain. Projects like these made possible the widespread cultural acceptance of Jews and Catholics as equal partners in national life during and after World War II. They provided a critical foundation, and an important precedent, for efforts that ultimately produced broad idealization of a protestant-Catholic-Jewish United States.

\footnotetext{
${ }^{72}$ Brown, Finding God in a New World, 35.
} 